\title{
Improving the methodology for assessing the technical condition of equipment during the transportation of energy carrier in energy systems and complexes
}

\author{
S. O. Gaponenko, ${ }^{1, *}$, R. Z. Shakurova ${ }^{1}, A . E$. Kondratiev $^{1}$, and $R$. Dimova ${ }^{2}$ \\ ${ }^{1}$ Kazan State Power Engineering University, Kazan, Russia \\ ${ }^{2}$ Technical University of Varna, Varna, Bulgaria
}

\begin{abstract}
The stable and uninterrupted work of the energy sector enterprises largely determines the economic development of the country. At the same time, the reliability of energy systems and complexes depends on the technical condition of the energy transportation equipment. In this regard, there is an urgent need to monitor the technical condition of the equipment. Currently, there are various types of nondestructive testing used for diagnostics, but none of them is universal, and many of them only allow to find defects of a certain type. In this connection, there is a topical issue of improving the methods for assessing the technical condition of equipment during the transportation of energy carriers in energy systems and complexes. This paper presents an information and diagnostic complex that implements the proposed technical solution and tests the methodology.
\end{abstract}

\section{Introduction}

Energy sector is a basic sector of the national economy. Reliable work of energy sector enterprises is a guarantee of the country's energy security and its stable economic growth.

However, at the moment, about $20 \%$ of all capacities at the enterprises of the energy industry is produced on end-of-life equipment, while the renewal of energy capacities and their major repairs are produced in irrational proportions. The growth of production capacity, a large degree of wear of equipment, as well as the wasteful energy consumption, all these factors introduce the energy industry to an area of heightened risk, technological failures, accidents, making the energy supply system less reliable [1].

The decision of these and other problems in the fueland-energy complex becomes essential. In this regard, the Federal Law No. 261-FZ "On Energy Saving and Improving Energy Efficiency and Amending Certain Legislative Acts of the Russian Federation" was adopted by the Government of the Russian Federation and the State Duma in November 23, 2009. Also the Government of the Russian Federation has adopted the order No. 1715-r "Energy Strategy of Russia for the Period up to 2030 (ES-2030)" in November 13, 2009 [2$6]$.

\section{Formulation of the problem}

To ensure reliable work of the energy system and, as a result, to ensure uninterrupted supply of thermal energy to consumers, special attention should be paid to the technical condition of the energy transportation equipment in energy systems and complexes [7, 8].

The main reasons for the high requirements for reliability and safety of heat and power equipment are human casualties and heavy financial and environmental damage in case of accidents caused by the destruction of energy equipment, buildings and constructions, as well as the termination of the production process for a long time $[9,10]$.

All this circumstances make it necessary to pay increased attention to the diagnosis and monitoring of the technical condition of energy equipment. Technical diagnostics is carried out regularly, and the methods and diagnostic tools currently in use make it possible to accurately determine the type of defect, its size and location. [11,12]. However, in practice, there are several diagnostic methods that are used to determine the technical condition of an object, but each of these methods allows to detect defects of a certain type. The scope of work on technical diagnostics and the type of the applied means of control depend on the design of the equipment, its features and its service life. [13-16].

In this regard, it is very important to improve the methodology for assessing the technical condition of equipment during the transportation of energy carriers in energy systems and complexes, which is the purpose of this work.

\footnotetext{
Corresponding author: sogaponenko@yandex.ru
} 


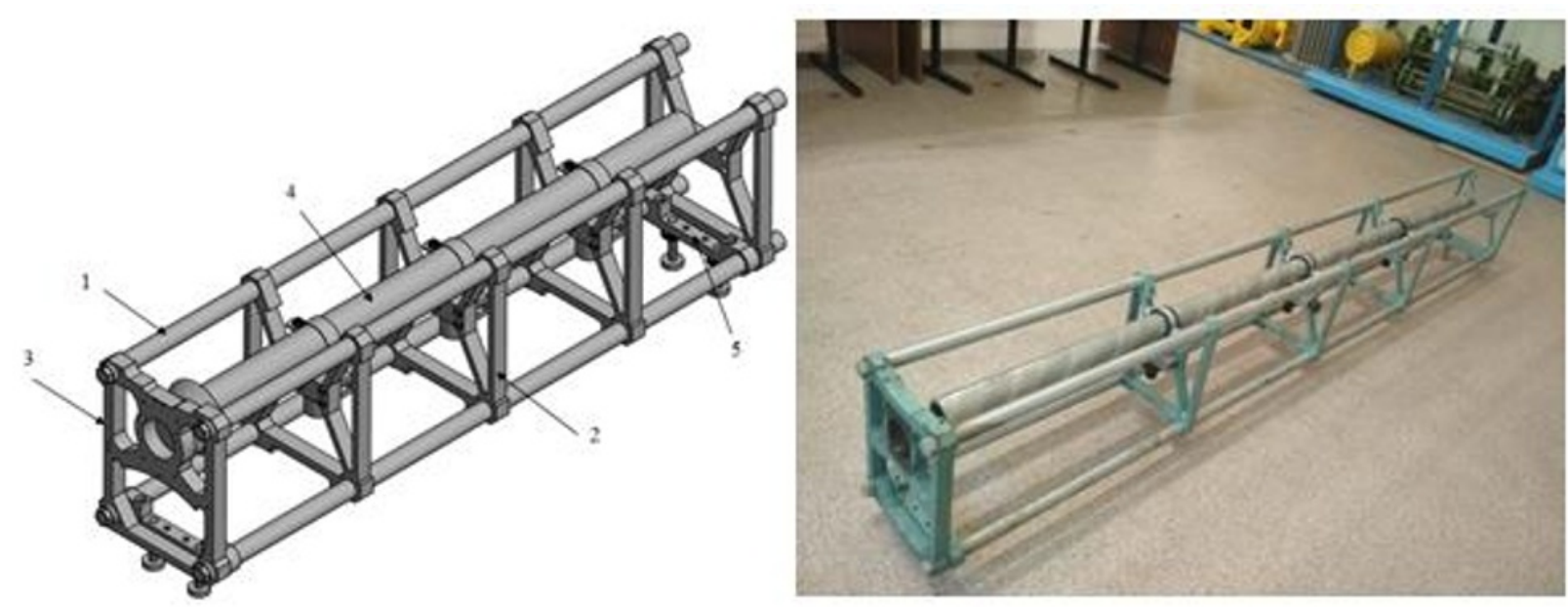

Fig. 1. Information and diagnostic complex: 1 - slideway; 2 - prop with clamp; 3 - prop with acoustic emitter; 4 - the investigated pipe; 5 - base with legs.

\section{Information and diagnostic complex}

An information and diagnostic complex (IDC) has developed to improve the methods of diagnosis of energy equipment.

The IDC (figure 1) consists of: the system of supports with clamps, which atteched the pipeline selected as the object of control, the complex also includes an excitation system consisting of an excitation device shown in figure 2 , and a registration system consisting of a sensing element and an analog-to-digital converter connected to a personal computer by electric communication.

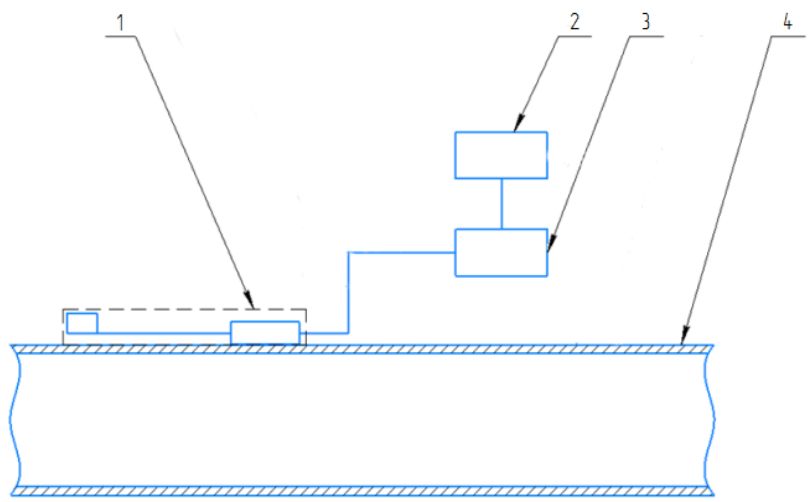

Fig. 2. Excitation device: 1 - inertial resonator, 2 - personal computer; 3 - digital-to-analog converter; 4 - the investigated pipe.

The principle of work of the IDC is as follows. The excitation device is attached to the pipeline, then with the help of a personal computer and digital-analog converter, this device is activated, it causes the vibration in the wall of the pipeline under study, then with the help of a sensing element made in the form of a microphone, the vibration parameters of the wall are measured, and then the obtained information is received to the personal computer through the analog-digital converter for registration and further analysis.
To control the vibration effect on the pipeline under study, as well as to collect, store and process signals coming from the microphone, a computer program "Condition monitoring system" was developed in LabVIEW [17,18]. Figure 3 shows the "Generation" program panel, in which the rotational speed of the inertial resonator can be controlled and adjusted. Figure 4 shows the "Registration" program panel, in which the signals from the microphone are recorded and converted to a spectrum for further analysis.

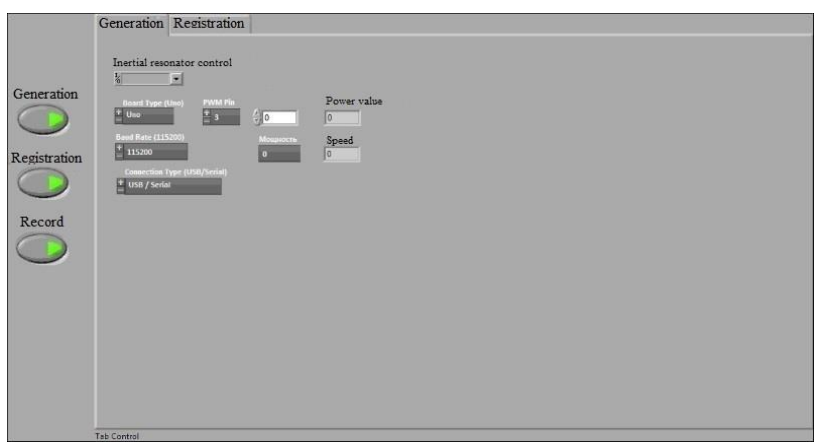

Fig. 3. "Generation" program panel.

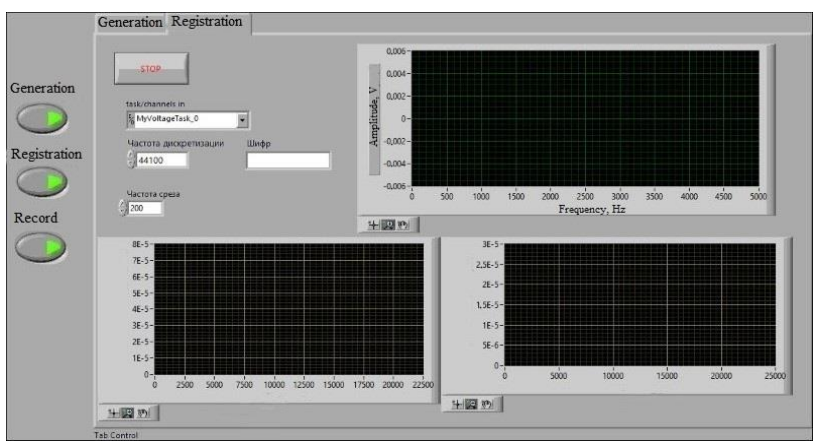

Fig. 4. "Registration" program panel. 


\section{Determination of natural frequencies of oscillations of the IDC for monitoring the technical condition of equipment}

As a result of the study, the modes of oscillations of the IDC are determined. When analyzing the results of the modal calculation, it is necessary to take into account that the form of free oscillations was calculated in relative units, and it did not allow determining absolute displacements.

The results are presented in table 1 .

Table 1. Calculation results.

\begin{tabular}{|c|c|c|c|}
\hline $\begin{array}{c}\text { Oscillation } \\
\text { mode number }\end{array}$ & $\begin{array}{c}\text { Frequency } \\
\text { Hz. }\end{array}$ & $\begin{array}{r}\text { Oscillation } \\
\text { mode number }\end{array}$ & $\begin{array}{c}\text { Frequency } \\
\text { Hz. }\end{array}$ \\
\hline 1 & 92.848 & 26 & 1014.3 \\
\hline 2 & 142.05 & 27 & 1028.3 \\
\hline 3 & 166.21 & 28 & 1063.1 \\
\hline 4 & 173.32 & 29 & 1119.7 \\
\hline 5 & 188.1 & 30 & 1140.7 \\
\hline 6 & 262.38 & 31 & 1175 \\
\hline 7 & 322.11 & 32 & 1220.8 \\
\hline 8 & 337.9 & 33 & 1262.6 \\
\hline 9 & 391.28 & 34 & 1268.2 \\
\hline 10 & 424.07 & 35 & 1284.8 \\
\hline 11 & 483.53 & 36 & 1325.8 \\
\hline 12 & 544.85 & 37 & 1331.4 \\
\hline 13 & 574.89 & 38 & 1396.9 \\
\hline 14 & 622.84 & 39 & 1424 \\
\hline 15 & 738.09 & 40 & 1438.6 \\
\hline 16 & 742.57 & 41 & 1441.5 \\
\hline 17 & 749.35 & 42 & 1456.6 \\
\hline 18 & 774.17 & 43 & 1484.8 \\
\hline 19 & 828.85 & 44 & 1502.7 \\
\hline 20 & 849.66 & 45 & 1541.3 \\
\hline 21 & 876.57 & 46 & 1555.6 \\
\hline 22 & 880.31 & 47 & 1609.1 \\
\hline 23 & 921.44 & 48 & 1616 \\
\hline 24 & 948.73 & 49 & 1638.6 \\
\hline 25 & 955.44 & 50 & 1661.7 \\
\hline
\end{tabular}

The oscillation mode shape of the fifteenth mode of the installation under study at a frequency of $738.09 \mathrm{~Hz}$ is presented in figure 5 .

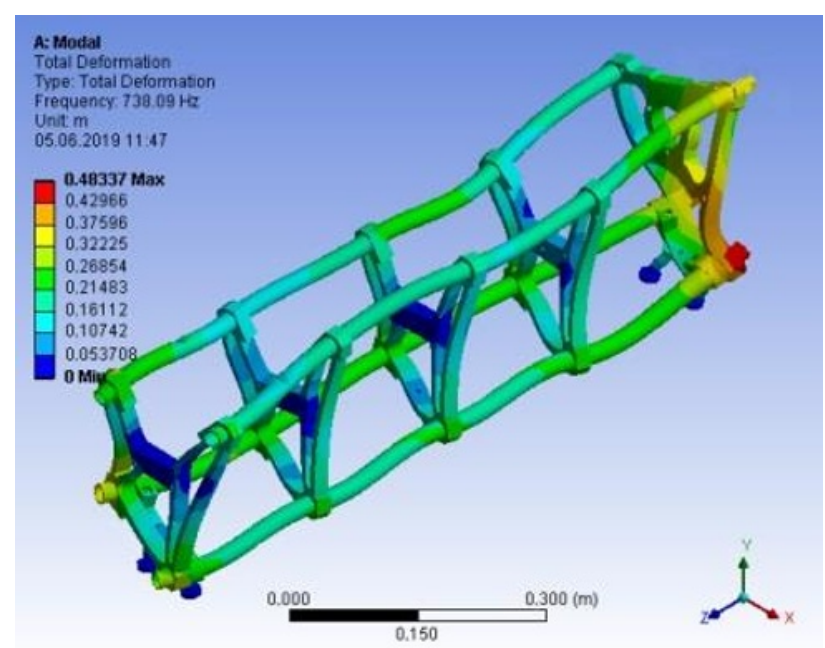

Fig. 5. Oscillation mode shape at frequency $738.09 \mathrm{~Hz}$.

\section{Laboratory tests}

During the experiment, an inertial resonator with a rotation frequency of $15,000 \mathrm{rpm}$ and an operating voltage of $3 \mathrm{~V}$ was used to excite oscillations in the wall of the pipeline under study. Adjusting the rotational speed of the inertial resonator motor is implemented on the Arduino Uno electronic platform.

The generated frequencies were recorded using a microphone. Figures 6 and 7 show photographs of the laboratory stand.

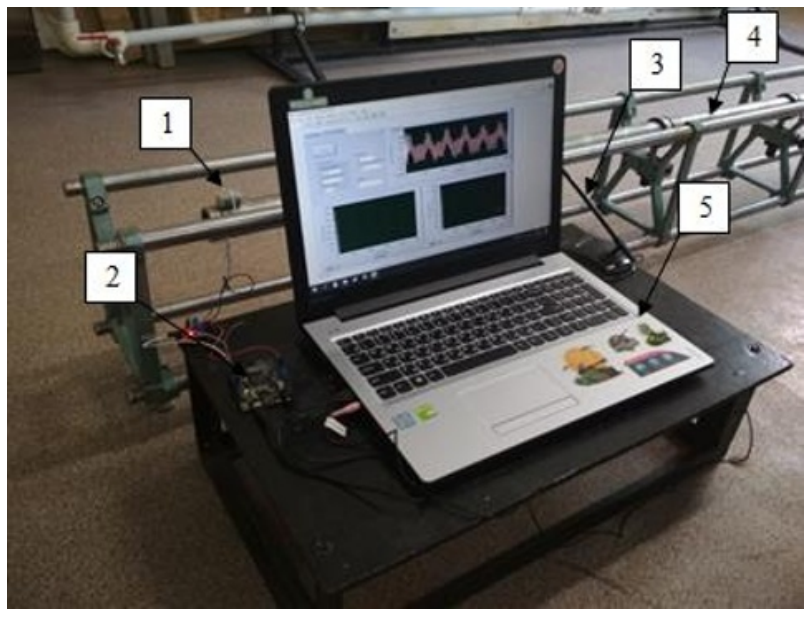

Fig. 6. The laboratory stand: 1 - inertial resonator; 2 - Arduino Uno Board; 3 - microphone; 4 - the investigated pipe; 5 personal computer.

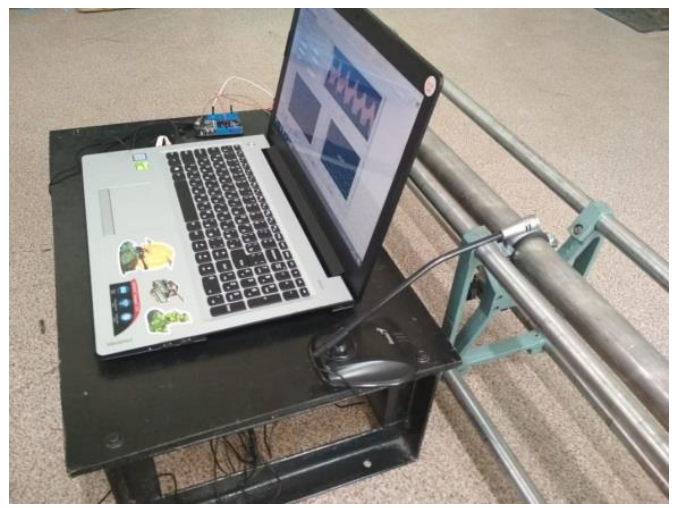

Fig. 7. Photograph of the laboratory stand.

The initial frequency of rotation of the inertial resonator is $100 \mathrm{~Hz}$, the measurement step is $10 \mathrm{~Hz}$, after $250 \mathrm{~Hz}$, the measurement step is $5 \mathrm{~Hz}$. Static and random error was $10 \%$.

On the graphs, the amplitude in $\mathrm{mV}$ is plotted on the vertical axis, and the frequency in $\mathrm{Hz}$ on the horizontal axis.

The measurement results at some frequencies are presented in figures $8-13$. 


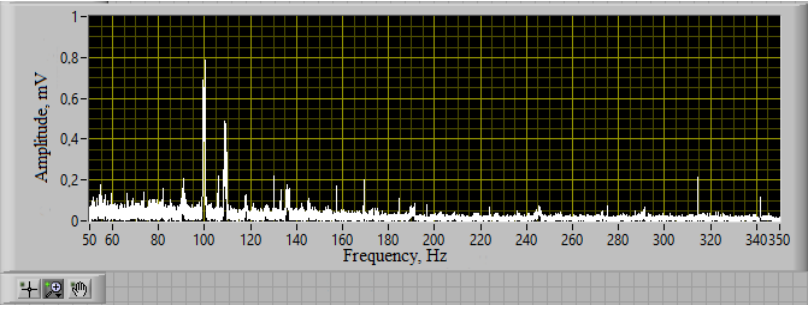

Fig. 8. Excitation frequency is $100 \mathrm{~Hz}$.

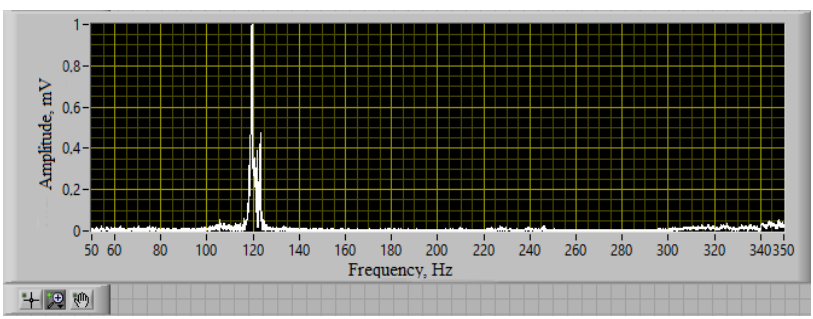

Fig. 9. Excitation frequency is $120 \mathrm{~Hz}$.

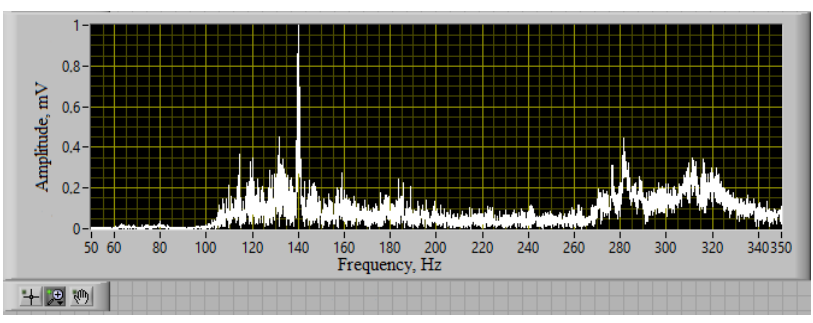

Fig. 10. Excitation frequency is $140 \mathrm{~Hz}$.

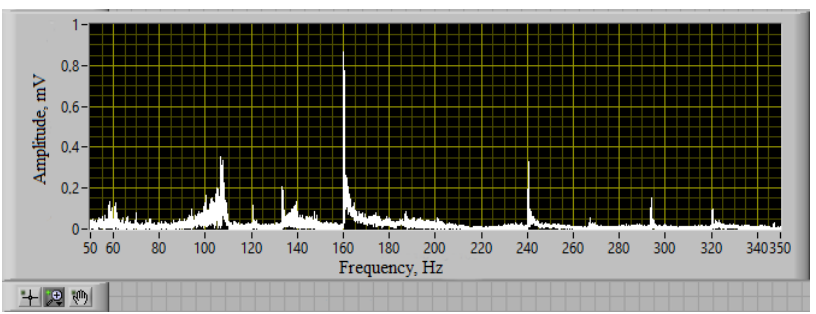

Fig. 11. Excitation frequency is $160 \mathrm{~Hz}$.

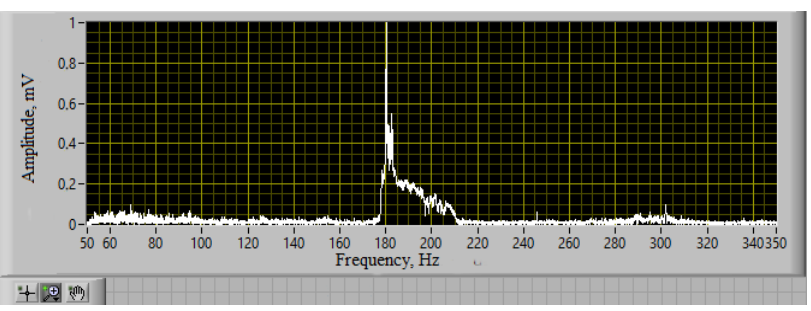

Fig. 12. Excitation frequency is $180 \mathrm{~Hz}$.

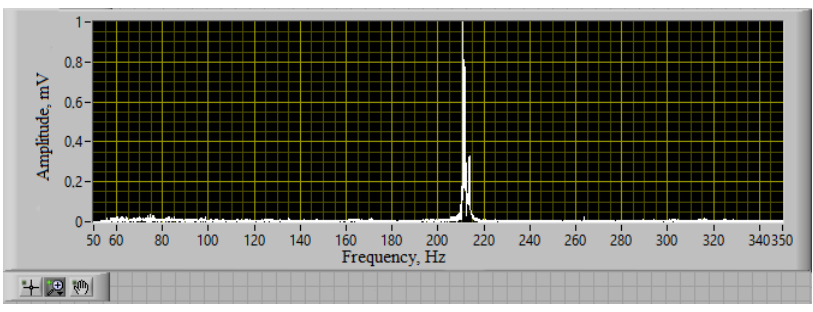

Fig. 13. Excitation frequency is $210 \mathrm{~Hz}$.

\section{Conclusion}

Analysis of the calculation results in the ANSYS software package and experimental data shows that the main modes of pipeline oscillations coincide with an average deviation of $3 \%$. The proposed method provides high accuracy of the assessment of the technical condition of equipment during the transportation of energy carriers in energy systems and complexes.

The developed technique is applicable in combination with other methods of non-destructive testing to improve the efficiency and reliability of the assessment of technical condition of the equipment

\section{References}

[1] E.A. Gavrilyuk, Information Decision-Support System on the Basis of the Method of Diagnostics and Control of the Technical State of Industrial Equipment. 12th International Scientific and Technical Conference "Dynamics of Systems, Mechanisms and Machines", Dynamics 20183 Article number 8601472 (2019)

[2] S.O. Gaponenko, Akustiko-rezonansnyj informacionno-izmeritel'nyj kompleks i metodika kontrolya mestopolozheniya zaglublennyh truboprovodov [Acoustic-resonant informationmeasuring complex and methods for monitoring the location of buried pipelines]. Extended Abstract of Cand. (Engineering Sci.) Dissertation, Kazan, KSPEU 22, (in Russian) (2017)

[3] S.O. Gaponenko, A.E. Kondratiev Model'naya ustanovka dlya razrabotki sposoba opredeleniya mestopolozheniya skrytyh truboprovodov [Model plant for developing a method for determining the location of hidden pipelines] Izvestiya vysshih uchebnyh zavedenij. Problemy energetiki. Kazan: KSPEU publ., 7-8, 123-129 (in Russian) (2014)

[4] S.O. Gaponenko, A.E. Kondratiev, Perspektivnye metody i metodiki poiska skrytyh kanalov, polostej i truboprovodov vibroakusticheskim metodom [Prospective methods and techniques for finding hidden channels, cavities and pipelines by the vibro-acoustic method] Vestnik Severo-Kavkazskogo federal'nogo universiteta. Stavropol: NCFU publ., 2(47), pp. 9-13. (in Russian) (2015)

[5] S.O. Gaponenko, A.E. Kondratiev Metodika poiska skrytyh polyh ob"ektov $\mathrm{v}$ grunte [Technique for finding hidden hollow objects in the ground] Nauchnomu progressu - tvorchestvo molodyh [Scientific progress - the creativity of young]. Yoshkar-Ola: VSUT publ., 2-4, 115-118 (2017)

[6] S.O. Gaponenko, A.E. Kondratiev Universal'naya metodika opredeleniya trassirovki skrytyh truboprovodov [Universal method for determining the trace of hidden pipelines] XII Mezhdunarodnaya molodezhnaya nauchnaya konferenciya «Tinchurinskie chteniya» [XII International Youth Scientific Conference "Tinchurin Readings"]. Kazan: KSPEU publ, 2, 74-76 (in Russian) (2017) 
[7] J. Zachwieja, Effectiveness of diagnosing damage to an industrial pump rotor by analysing its vibrations / Zachwieja, J. // Diagnostyka. 20(1), 33-39 (2019)

[8] J. Zachwieja, Pipeline stress analysis under supporting structure vibrations / Zachwieja, J. // Diagnostyka. 18(2), 23-30 (2017)

[9] Y. Stein, Development and improvement of methods of diagnostics of heating systems in modern conditions. IOP Conference Series: Earth and Environmental Science. 90(1), Article number 012139 (2017)

[10] L.S. Moscoso. Statistical parameters extraction of the vibration signals of a gearbox for machine diagnosis INTER-NOISE - 44th International Congress and Exposition on Noise Control Engineering (2015)

[11] N.A. Cheraghi, novel approach for detection of damage in adhesivelybonded joints in plastic pipes based on vibration method using piezoelectric Conference Proceedings - IEEE International Conference on Systems, Man and Cybernetics 4, 3472-3478 (2005)

[12] O. Hunaidi, Acoustical characteristics of leak signals in plastic water distribution pipes / Hunaidi, O., Chu, W.T // Applied Acoustics 58(3), 235-254 (1999)

[13] S.O. Gaponenko, et. al. Sposob opredeleniya raspolozheniya truboprovoda [The method of determining the location of the pipeline]. Patent RF, no. 2482515, 2013.

[14] S.O. Gaponenko, Low-frequency vibro-acoustic method of determination of the location of the hidden canals and pipelines. Procedia Engineering. 150, 23212326 (2016)

[15] S.O. Gaponenko, Determination of informative frequency ranges for buried pipeline location control. Helix 8(1), 2481-2487 (2018)

[16] S.O. Gaponenko, A.E. Kondratiev Izmeritel'nodiagnosticheskij kompleks dlya opredeleniya raspolozheniya skrytyh truboprovodov [Measuring and diagnostic complex to determine the location of hidden pipelines] Izvestiya vysshih uchebnyh zavedenij. Problemy energetiki. Kazan: KSPEU publ., 3-4, 138-141 (in Russian) (2013)

[17] S.O. Gaponenko, et. al. Contactless monitoring system Certificate of state registration RF, 2019617616, 18.06.2019.

[18] V.P. Fedosov, Cifrovaya obrabotka zvukovyh $i$ vibrosignalov $v$ LabVIEW [Digital processing of sound and vibrosignals in LabVIEW]. Moscow: DMK Press, , 1289 (in Russian) (2009) 